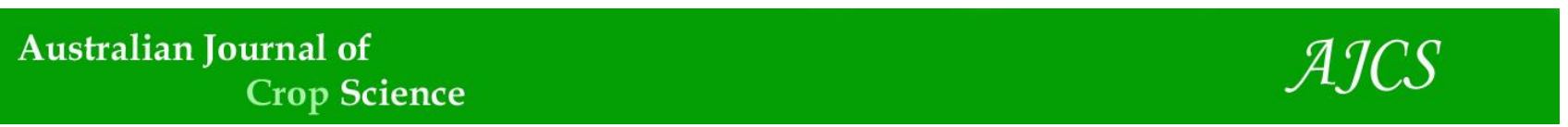

AJCS 15(03):394-400 (2021)

ISSN:1835-2707

doi: 10.21475/ajcs.21.15.03.p2851

\title{
Physiological and oxidative defense responses of local rice cultivars "Nusa Tenggara Timur-Indonesia" during vegetative drought stress
}

\author{
Yustina Carolina Febrianti Salsinha ${ }^{1}$, Didik Indradewa ${ }^{2}$, Yekti A. Purwestri ${ }^{1,3}$, Diah Rachmawati ${ }^{1, *}$ \\ ${ }^{1}$ Department of Tropical Biology, Faculty of Biology, Universitas Gadjah Mada, Yogyakarta, Indonesia \\ ${ }^{2}$ Department of Agronomy, Faculty of Agriculture, Universitas Gadjah Mada, Yogyakarta, Indonesia \\ ${ }^{3}$ Research Center for Biotechnology, Universitas Gadjah Mada, Yogyakarta, Indonesia
}

\section{*Corresponding author: drachmawati@ugm.ac.id}

\begin{abstract}
Drought is the main abiotic factor that reduces productivity of crops such as rice in the suboptimum area. This study aimed to identify drought-tolerance of local rice cultivars "Nusa Tenggara Timur-Indonesia" through their oxidative defense mechanism. In this study, 17 local rice cultivars and two control cultivars (Ciherang and Situ Bagendit) were used. Drought was imposed by using three levels of FTSW: FTSW 1 (control), 0.5 (moderate drought), and 0.2 (severe drought) during the vegetative stage. Growth parameters such as plant height, number of tillers, number of leaves, and total dry weight were higher in Boawae 100 Malam, Hare Tora, and Padi Putih Kuatnana than other cultivars. The analysis of relative water content, chlorophyll, carotenoid, and proline content also indicated that the Boawae 100 Malam, Gogo Sikka, and Hare Tora cultivar showed a higher result compared to control and other cultivars. These characters tend to correlate with the higher activity of antioxidant enzymes in Boawae 100 Malam and Gogo Sikka, when exposed to severe drought conditions. Based on principal component analysis of the physiological changes and enzymatic antioxidant activity, the Gogo Sikka, Boawae 100 Malam, and Hare Tora cultivars were classified as rice cultivars with higher drought tolerance.
\end{abstract}

Keywords: antioxidant, drought-tolerant, enzymatic, FTSW, traditional rice.

Abbreviations: APX_Ascorbate Peroxidase, CAT_Catalase, DAP_Day after planting, FTSW_Fraction of Transpirable Soil Water, NTT_Nusa Tenggara Timur, ROS_Reactive Oxygen Species, SOD_Superoxide Dismutase, TTSW_Total Transpirable Soil Water

\section{Introduction}

Plants experience drought or water deficit due to climate changes and fluctuations of environmental temperatures less or more than optimum. The effects of drought on plants depend on the water holding capacity of soil particles and the rate of plant evapotranspiration (Aroca and Ruiz-Lozano, 2012). Water stress reduces agricultural production throughout the world, and the need to increase the adaptation of crops and the selection of tolerant cultivars is becoming urgent (Pandey and Shukla, 2015).

Rice (Oryza sativa L.) is a crop that evolves in tropical and subtropical regions and is generally sensitive to drought. Cultivation of drought-tolerant rice cultivars needed two factors: 1) accession of drought-tolerant upland rice as a parental donor and 2) effective evaluation methods for the selection process (Xia et al., 2016). According to Pandey and Shukla (2015), a comprehensive study of various morphological, physiological, and biochemical characteristics can be used to predict patterns of drought tolerance and the response mechanism of drought-tolerant plants.

During vegetative drought stress, plants experience several physiological changes. These include increase in antioxidant activity, changes in stomatal conductance and root characteristics, higher level of osmotic adjustment, higher transpiration rate, and changes in biosynthesis and catabolism of phytohormone like ABA (Pandey and Shukla,
2015; Salsinha et al., 2020). During drought stress, plants experience lower root and shoot development as a result of water deficit (Tripathy et al., 2000; Pandey and Shukla, 2015).

A common side effect is a reduction in cell division, which has significant implications on decline in shoots fresh and dry weight (Centritto et al., 2009). Drought also reduces turgor pressure under stressful conditions and triggers a decrease in the photosynthesis rate by lowering the concentration of $\mathrm{CO}_{2}$ absorbed by leaf tissue (Pandey and Shukla, 2015). As a result of this process, the photosynthetic pigments continued to be disturbed during the dehydration phase (Ashraf, 2011).

The disruption of photosynthesis and metabolism due to drought causes higher production of reactive oxygen species (ROS) (Mittler, 2002; Ashraf, 2011). When conditioned at a low level, ROS acts as a component of the secondary messenger in the stress signaling pathway during drought stress and initiates the autophagy process. When the accumulation of ROS reaches its phytotoxicity level, it leads to an uncontrolled oxidation process, causing cell membrane damage (Mittler, 2002).

To overcome cell damage due to ROS production, plants respond by developing oxidative defense systems. This defense system includes the activation of superoxide 
dismutase (SOD), ascorbate peroxidase (APX), catalase (CAT), and glutathione reductase (GR) as an enzymatic antioxidant defense (Siswanti and Rachmawati, 2011; Refli et al., 2014; Singh et al., 2015). Several rice cultivars are known to have a high tolerance to drought according to the antioxidant level of the cell (Pandey and Shukla, 2015; Singh et al., 2015).

The East Nusa Tenggara (NTT) region consists of several islands, including Timor, Sumba, Flores, Alor, Rote, and another island consists of various geographical conditions that are dominated by dry climates. The average rainfall in the NTT is about 0-12 mm in May-October and 50-300 mm from November to April. The need to improve food production in this region has directed agricultural objectives to the development of tolerant rice cultivars.

NTT has a local upland seed germplasm, which ranges from 21 upland rice accessions cultivated through traditional techniques based on Lalel (2009). NTT has 91 accessions of food crops including 20 local upland rice accessions spread across 11 districts in NTT. Each rice cultivar has specifically adapted to its environment so that the potential for crop variations with high adaptation to drought is also high in the regions of NTT dominated with a dry climate (Mau et al., 2019). However, Indonesia has been experiencing the loss of thousands of local rice cultivars until 2008.

In order to obtain drought tolerant local rice cultivars, this study will examine morphophysiological characters and their relationship with enzymatic antioxidant defense to identify drought-tolerant rice cultivars.

\section{Results and Discussion}

Drought stress is a limiting factor affecting the growth rate and productivity of food crops. The ability of a plant to adapt to various environmental conditions with different moisture content is related to plasticity and photosynthetic resilience combined with many processes in controlling plant growth and development in the environment (Chaves et al., 2011). Through the identification of regulatory mechanisms in morphological, physiological, and oxidative defense responses, a group of cultivars that are tolerant to drought can be obtained.

\section{Growth phenotype characters}

Drought stress significantly decreased the phenological character in the plant. The development process from the vegetative to the reproductive phase has also been reduced due to limited available water (Farooq et al., 2012). It also causes cell membrane damage, which has implications for cell death. A study conducted on Triticum aestivum L. and Hordeum vulgare $\mathrm{L}$. showed that an increase in stress level decreases the total duration of growth (McMaster and Wilhelm, 2003). However, each plant species has different responses in different groundwater levels (Farooq et al., 2012).

Table 1 indicates the decreasing percentage of growth characteristics (plant height, number of tillers, and plant dry weight) significantly $(p<0.05)$ along with the increase in drought stress level. The formation of shoots, number of tillers, and plant biomass depend on cell division, expansion, and differentiation activities (Farooq et al., 2012; Salsinha et al., 2020).

Reduction of water supply in planting medium below the optimum point for the physiological process of the plant negatively affects cell's turgor pressure, suppressing cell division and inhibits the cell growth (Neumann, 2011). An increasing level of drought stress has significant effects on drought-susceptible plants showed by a higher reduction percentage of each parameter. This reduction percentage can be obtained by comparing the phenotypic characteristics in the control condition to severe drought conditions (Farooq et al., 2012).

The reduction analysis of growth (Table 1) shows that drought-tolerant cultivar are Boawae 100 Malam and Padi Merah Kuatnana with the smallest reduction percentage of $24.2 \%$ and $20.9 \%$ for plant height, $7.14 \%$ and $41.18 \%$ for the number of tillers, and $28.2 \%$ and $26.7 \%$ for the number of leaves, respectively. This reduction percentage was significantly different $(p<0.05)$ from Ciherang cultivar. While for the same growth parameters, cultivars with high susceptibility to drought stress with higher reduction percentage are Padi Putih Maumere, and Padi Merah Noemuti.

When plants were exposed to drought, turgor pressure will decrease which inhibits growth (Neumann, 2011). This condition is compounded by the increase in ROS production as a result of the loss of cell turgor pressure and stomatal closure during drought stress. As a result, plants will experience a decrease in the rate of carbon assimilation, which has an impact on decreasing plant biomass.

\section{Relative Water Content and Leaf Rolling Score}

In drought conditions, plants also experience the increase of cell osmotic potential, causing a rapid loss of physiological water from the cell. This leads to the change of relative water content (RWC), the parameter was used to evaluate the cell osmotic response during drought. In this condition, RWC will drop until it reaches the point of osmotic equilibrium between the internal and external conditions of the cell (Farooq et al., 2012).

In this study, the water status indicated by the RWC shows the actual water content ratio relative to the maximum water binding capacity in turgid conditions (Mullan and Pietragalla, 2011). A cultivar with higher RWC can minimize stress by regulating optimum leaf turgor pressure under drought stress conditions (Bacellar et al., 2011; Mullan and Pietragalla, 2011).

A high level of drought stress (FTSW 0.2) corresponds to a small RWC percentage in plant tissue but with high leaf rolling scores. This condition is associated with a decrease in cell turgor pressure. Based on the data (Table 2), several cultivars generally show significant differences $(p<0.05)$ between RWC and changes in leaf rolling scores during drought conditions. A small increase in the leaf rolling score from control to severe drought condition corresponds to the plant's ability to allocate the water content in the cell to maintain the turgor pressure.

Each cultivar shows a high leaf rolling score with a low RWC. The higher the leaf rolling score is, the more a cultivar sensitive to water stress. Higher leaf rolling scores can be seen in Padi Putih Maumere cultivar in FTSW 0.2 (severe). The lowest leaf rolling scores (more tolerant) were shown by the Boawae 100 Malam, Hare Tora, and Pak Mutin cultivars. These results suggest that each cultivar that has different leaf rolling scores responds differently to changes in the water status in the leaf tissue.

\section{Changes in proline levels}

Proline is an osmoprotectant in the amino acid group. Proline plays important roles in maintaining osmotic and 
oxidative stress and also acts as a sub-cellular structure (membranes and proteins) stabilizers, regulators of NADP+/NADPH ratio, and a protein hydrotrope (Hayat et al., 2012). The data (Table 2) show that plants experience increase in proline levels as a result of the induced drought stress in roots. Several cultivars have shown the highest level of proline level from control to severe drought conditions including Shintara, Padi Merah Noemuti, Boawae 100 Malam, Padi Hitam Maumere, and Gogo Sikka, with percentages of $35.96 \%, 31.35 \%, 41.31 \%, 49.18 \%$, and $47.99 \%$, respectively.

As a defense mechanism against drought, proline biosynthesis is induced directly during stress. Research shows that proline is responsible for scavenging ROS and other free radicals. However, the application of exogenous proline at excess levels $(40-50 \mathrm{mM})$ has a low growth effect on rice plants with abiotic stress (Hayat et al., 2012).

\section{Photosynthetic Pigment Characteristics}

The photosynthetic performance of a plant can be observed from chlorophyll pigment changes. In a severe drought condition, an increase in leaf rolling scores leads to a decreasing photosynthesis rate, especially in carbon assimilation reactions. As a result of stomatal closure, decreased $\mathrm{CO}_{2}$ availability leads to a reduction of the carboxylation process by Rubisco (Chaves et al., 2011).

Based on the data (Table 2), cultivars with a lower reduction percentage of chlorophyll content (Hare Tora and Boawae 100 Malam with $9.37 \%$ and $7.56 \%$, respectively) tend to have a high tolerance to drought. Cultivars with the highest decrease in chlorophyll levels or a high drought sensitivity are Pak Mutin, Gogo Jak, and Padi Putih Maumere, with percentages of $34.65 \%, 34.38 \%$, and $43.28 \%$, respectively. An imbalance in PSII photochemical activity and electron transport for photosynthesis also occurs after a long period of drought stress. These cause a limitation on the assimilation rate, as indicated by a decrease in chlorophyll levels (Chaves et al., 2011). This situation leads to the decreased accumulation of the assimilation process, which affects the decreasing cell biomass. The data in Table 2 show that plants experience a decrease in chlorophyll pigment contents in line with the reduction in total biomass (significantly different with $\mathrm{p}<0.05$ ) for each cultivar. Therefore, a decrease in chlorophyll content under drought conditions affects the formation of total plant biomass.

\section{Enzymatic antioxidant response}

Chloroplast, mitochondria, peroxisome, plasma membrane, and apoplast normally produce ROS during the respiration and photosynthesis processes. However, the effects of water deficit on plants encourage the increasing accumulation of ROS in cells (Mittler, 2002; Refli and Purwestri, 2016). Increased levels of $\mathrm{ROS}\left(\mathrm{O}_{2^{*}} ; \mathrm{H}_{2} \mathrm{O}_{2} ;\right.$ and $\left.{ }^{*} \mathrm{OH}\right)$ leads to oxidation of lipid molecules, DNA, and protein inactivation and inhibition of various enzymes in metabolic processes (Foyer and Noctor 2003; Mittler, 2002).

ROS were produced sufficiently during drought stress in photosystem I (PSI) and photosystem II (PSII). In general, superoxide is one of the ROS that is produced predominantly in the PS I and the Mehler reaction (Gechev et al., 2006). The resulting superoxide then catalyzes into $\mathrm{H}_{2} \mathrm{O}_{2}$ by superoxide dismutase (SOD). Singlet accumulation of oxygen is also produced through the excitation of chlorophyll at the PS II reaction center as a negative consequence of increased drought stress. (Mittler, 2002; Foyer and Noctor, 2003).
The data (Table 3 ) shows the SOD of each cultivar was significantly different at each level of treatment $(P<0.05)$. During drought conditions, the Padi Merah Noemuti, Gogo Metan, and Mapan cultivars showed high SOD activity during drought stress, with values of $45.8,45.3$, and $30 \mathrm{U} \mathrm{L}^{-1}$, respectively. SOD acts as a dismutase enzyme that catalyzes singlet oxygen $\left(\mathrm{O}_{2-}{ }^{*}\right)$ into $\mathrm{H}_{2} \mathrm{O}_{2}$. Several cultivars that have high SOD activity shows a lower level of cell damage than other cultivars. SOD activity also increased at the beginning of the stress period and decreased in line with the increase in the drought stress period (Mittler, 2002).

Another enzyme in the enzymatic antioxidant system is catalase (CAT), which is an enzyme that converts peroxide into $\mathrm{O}_{2}$ and $\mathrm{H}_{2} \mathrm{O}$. The difference in activity with APX is that CAT does not require ascorbic acid as an electron donor (Foyer and Noctor, 2003). The enzymatic activity of CAT in several rice cultivars increased until the third day after drought stress and then decreased in line with the increase in the stress period. However, CAT activity depends on cultivars, the types of abiotic stress, and the drought stress phase (Gechev et al., 2006). Based on the data (Table 3), severe drought conditions (FTSW 0.2) increased CAT antioxidant enzyme activity in the vegetative phase but with no significant differences $(p<0.05)$ between each cultivar. These conditions lead to the late process of CAT activity during early drought treatment.

In addition to SOD and CAT, another important antioxidant enzyme is ascorbate peroxidase (APX). This enzyme is involved in the oxidative chain reaction that converts $\mathrm{H}_{2} \mathrm{O}_{2}$ into $\mathrm{O}_{2}$ and $\mathrm{H}_{2} \mathrm{O}$ with ascorbic acid (non-enzymatic antioxidant) as one of the electron donors (Refli and Purwestri, 2016). The data (Table 3) shows that severe drought conditions lead to an increase in APX antioxidant enzyme activity in the vegetative phase but with no significant differences $(p<0.05)$ between each cultivar. This condition also leads to the late process of APX activity during early drought treatment. A comparison of activities between each stress level shows an increasing pattern from control conditions (FTSW 1) toward severe drought (FTSW 0.2) both in CAT and APX activity.

\section{Principal Component Analysis (PCA)}

The data from PCA analysis (Fig.2a) revealed a $90.2 \%$ correlation of parameters affected by different levels of drought in various cultivars. The results show PC 1 (principal component 1) was correlated positively with parameters affected by drought include TDW, SDW, RDW, SFW, APX, ROS, CAT, AND SOD. This PC 1 also tends to correlate negatively with $\mathrm{CHL}, \mathrm{PRO}, \mathrm{CAR}, \mathrm{RWC}, \mathrm{SCO}$ by $60.1 \%$. From the same data PC 2 (principal component 2) is known to correlate positively with almost all parameters with a correlation percentage of $30.1 \%$.

Among all cultivars (Fig. 2b), Boawae 100 Malam(12), Gogo Sikka (17), Situ Bagendit (19), Kisol Manggarai (11), Hare Tora (6), Gogo Pulut Merah (3), and Pak Morin (1) were considered drought-tolerant cultivar. Otherwise, the cultivar of Shintara (2), Padi Merah Noemuti (9), Padi Hitam Maumere (15), Padi Putih Maumere (16), and Ciherang (18) were considered being drought susceptible.

The high level of drought can increase the ROS and corresponded linearly with the increase in the antioxidant activity of SOD, APX, and CAT. During drought conditions, plants experienced a decrease in physiological 
Table 1. Plant growth characteristics (plant height, tiller number, shoot dry weight, and root dry weight) of 17 NTT local rice cultivars as affected by decreasing FTSWs.

\begin{tabular}{|c|c|c|c|c|c|c|c|c|c|c|c|c|}
\hline \multirow{2}{*}{$\begin{array}{l}\text { Cultivar } \\
\text { FTSW } \\
\end{array}$} & \multicolumn{3}{|c|}{ Plant Height $(\mathrm{cm})$} & \multicolumn{3}{|c|}{ Tiller Number } & \multicolumn{3}{|c|}{ Shoot Dry Weight } & \multicolumn{3}{|c|}{ Root Dry Weight } \\
\hline & 1 & 0.5 & 0.2 & 1 & 0.5 & 0.2 & 1 & 0.5 & 0.2 & 1 & 0.5 & 0.2 \\
\hline PM & $110.6^{\text {cdef }}$ & $91.9^{f g h}$ & $79.7^{\text {def }}$ & $4.6^{a}$ & 3.6 & $4.0^{a b}$ & $18.54^{c d}$ & $15.53^{\text {de }}$ & $10.61^{d e}$ & $0.77^{b}$ & $0.59^{a}$ & $0.42^{\text {abcde }}$ \\
\hline SH & $87.5 a b c$ & $72.4^{b c d}$ & 62.9 abcde & $12.4^{c d}$ & $8.4^{\text {cde }}$ & 8.2 & $25.4^{j k}$ & $14.54^{c d}$ & $10.70^{d e}$ & $0.75^{b}$ & $0.54^{a}$ & $0.33^{a b}$ \\
\hline GPM & $117.7^{e f}$ & $96.3^{\mathrm{gh}}$ & $86.3^{f}$ & $5.4^{a}$ & 4.4 & $4.2^{a b}$ & $19.53^{\text {de }}$ & $12.56^{a b}$ & $12.05^{\text {ef }}$ & $0.75^{b}$ & $0.52^{a}$ & $0.46^{\text {abcde }}$ \\
\hline $\mathrm{CM}$ & $80.7^{a b}$ & $65.2^{a b c}$ & $56.5^{a b}$ & $12.6^{d}$ & $10^{e}$ & $9.8^{e}$ & $21.54^{f g}$ & $16.55^{e}$ & $8.99 a b c$ & $0.77^{b}$ & $0.58^{a}$ & $0.41^{\text {abcde }}$ \\
\hline MPP & $75.2^{a}$ & $67 a b c$ & $45.7^{a}$ & $9.6 \mathrm{bcd}$ & $6.0^{a b c d}$ & $6.4^{b c d}$ & $24.50^{i j}$ & $13.54 b c$ & $13.00^{f}$ & $0.73^{b}$ & $0.63^{a}$ & 0.47 abcde \\
\hline HT & $116^{\text {def }}$ & $93.7^{\mathrm{gh}}$ & $82.5^{e f}$ & $5.0^{a}$ & $6.2^{\text {abcd }}$ & $4.8^{a b c}$ & $17.59 b c$ & $12.55^{a b}$ & $10.56^{\text {cde }}$ & $0.74^{b}$ & $0.61^{a}$ & 0.55 bcde \\
\hline GF & $87.5^{a b c}$ & $75.8^{\text {cde }}$ & $64.4^{\text {abcde }}$ & $9.2^{b c}$ & $6.4^{a b c d}$ & $6.2^{b c d}$ & $18.54^{c d}$ & $11.53^{a}$ & $9.89 \mathrm{bcd}$ & $0.77^{b}$ & $0.56^{a}$ & 0.43 abcde \\
\hline GJ & $110.4^{\text {cdef }}$ & $94.3^{\mathrm{gh}}$ & $78.8^{\text {def }}$ & $6.0^{a}$ & $5.8^{a b}$ & $4.4^{a b}$ & $16.56^{a b}$ & $14.54^{c d}$ & $11.59^{e f}$ & $0.74^{b}$ & $0.61^{a}$ & $0.48^{\text {abcde }}$ \\
\hline PMN & $91.8^{a b c d}$ & 72.1 bcd & $59.3^{\text {abcde }}$ & $11.8^{c d}$ & $9.6^{e}$ & $7.0^{b c d}$ & $21.50^{f g}$ & 15.59 de & $7.94^{a}$ & $0.72^{b}$ & $0.49^{a}$ & 0.47 abcd \\
\hline GM & $108.6^{\text {cdef }}$ & $84.8^{e f g}$ & $76.8^{\text {cdef }}$ & $10^{b c d}$ & $8.6^{d e}$ & $6.6^{b c d}$ & $17.53^{b c}$ & $16.53^{e}$ & $12.61^{f}$ & $0.75^{b}$ & $0.57^{a}$ & $0.36^{a b c d}$ \\
\hline CK & $107^{\text {cdef }}$ & $81.3^{\text {def }}$ & $77.2^{\text {def }}$ & $4.2^{a}$ & $4.6^{a b}$ & $4.2^{a b}$ & $15.56^{a}$ & $13.57 b c$ & $10.52^{\text {cde }}$ & $0.75^{b}$ & $0.57^{a}$ & $0.56^{\text {cde }}$ \\
\hline BSM & $107.8^{\text {cdef }}$ & $100.2^{h}$ & 81.7 ef & $5.6^{a}$ & $5.2^{a b}$ & $5.2^{a b c}$ & $15.51^{a}$ & $14.54^{c d}$ & $8.51^{a b}$ & $0.72^{b}$ & $0.61^{a}$ & $0.58^{d e}$ \\
\hline PMK & $99.6^{\text {bcde }}$ & $104.2^{h}$ & $78.8^{\text {def }}$ & $6.8^{a b}$ & $5.6^{a b c}$ & $4.0^{a b}$ & $20.51^{\text {ef }}$ & $16.54^{e}$ & $12.62^{f}$ & $0.74^{b}$ & $0.56^{a}$ & 0.37 abcde \\
\hline PPK & $110.4^{\text {cdef }}$ & $96.7^{\mathrm{gh}}$ & $76.1^{\text {bcdef }}$ & $7.2^{a b}$ & $4.0^{a}$ & $4.2^{a b}$ & $21.46^{f g}$ & $13.54^{b c}$ & $9.62^{b c d}$ & $0.65^{b}$ & $0.54^{a}$ & $0.49^{e}$ \\
\hline PHM & $125.6^{f}$ & $99^{h}$ & $76.1^{\text {bcdef }}$ & $4.4^{a}$ & $4.0^{a}$ & $4.0^{a b}$ & $23.52^{h i}$ & $14.53^{c d}$ & $8.62^{a b}$ & $0.73^{b}$ & $0.59^{a}$ & $0.35^{a b c d}$ \\
\hline PPM & $101.5^{d e f}$ & $99.7^{h}$ & 75.6 bcdef & $5.0^{a}$ & $4.2^{a}$ & $2.6^{a}$ & $18.52^{c d}$ & $15.55^{d e}$ & $7.51^{a}$ & $0.74^{b}$ & $0.58^{a}$ & $0.50^{\text {abcde }}$ \\
\hline GS & $100.4^{\text {bcde }}$ & $58.7^{a}$ & $56.9 a b c$ & $9.8^{\mathrm{bcd}}$ & $9.8^{e}$ & $7.4^{\text {cde }}$ & $26.51^{k}$ & $16.58^{e}$ & $8.62^{a b}$ & $0.73^{b}$ & $0.51^{a}$ & $0.32^{a}$ \\
\hline $\mathrm{CH}$ & $75.8^{a}$ & $62.6^{a b}$ & $51.5^{a}$ & $10^{b c d}$ & $8.2^{c d e}$ & $6.4^{b c d}$ & $20.58^{e f}$ & $13.55^{b c}$ & $7.84^{a}$ & 0.76 & $0.61^{a}$ & $0.31^{a}$ \\
\hline SB & $78.4^{a b}$ & $63.7 a b c$ & $56.1^{a b}$ & $9.4 \mathrm{bcd}$ & $7.2^{\text {bcde }}$ & $5.2^{a b c}$ & $22.62^{g h}$ & $14.57^{c d}$ & $9.64 \mathrm{bcd}$ & 0.88 & $0.60^{a}$ & $0.34 a b c$ \\
\hline
\end{tabular}

Mean value followed by the same letters in the same column and row of each parameter indicate no significant differences based on the Duncan test at $\mathrm{P}<0.05$ and two-way ANOVA. Treatment was conducted using FTSW level 1 (control), 0.5 (moderate drought), and 0.2 (severe drought).

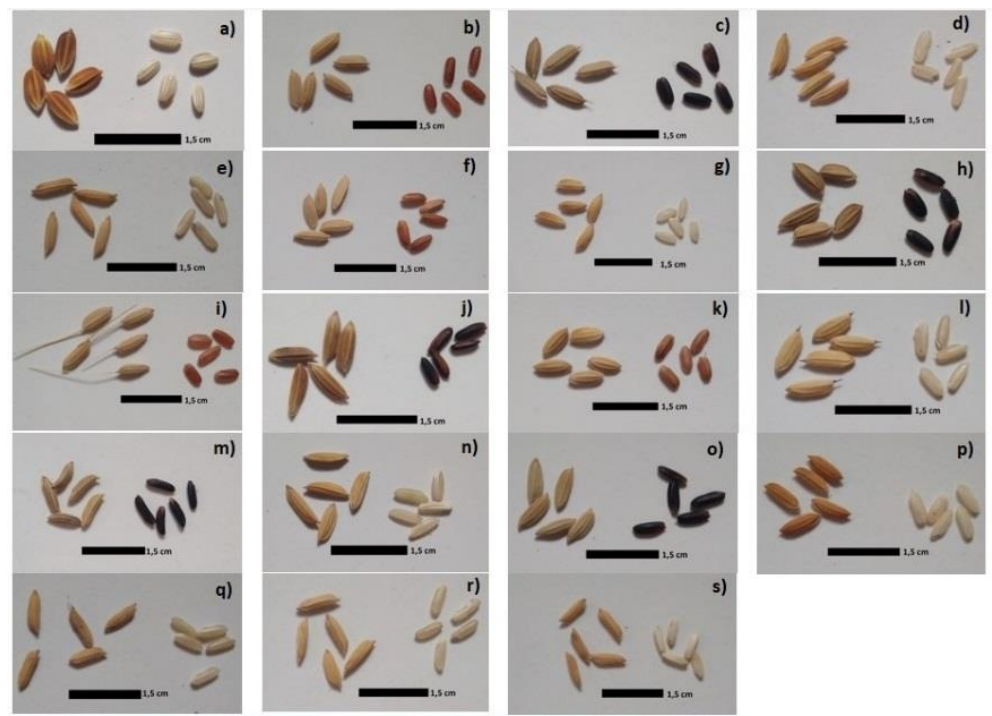

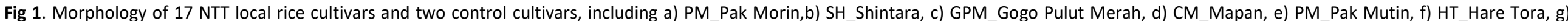

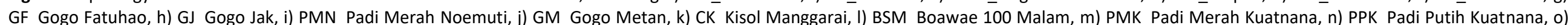

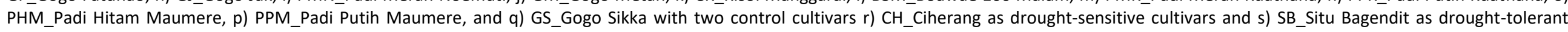
cultivars. Bars: $1.5 \mathrm{~cm}$ 


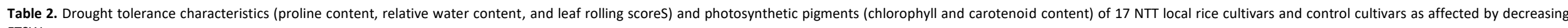

\begin{tabular}{|c|c|c|c|c|c|c|c|c|c|c|c|c|c|c|c|}
\hline \multirow{2}{*}{ Cultivar } & \multicolumn{3}{|c|}{ Proline content $\left(\mu \mathrm{mol} \mathrm{g}{ }^{-1} \mathrm{FW}\right)$} & \multicolumn{3}{|c|}{ Relative Water Content (\%) } & \multicolumn{3}{|c|}{ Leaf Rollling Scores } & \multicolumn{3}{|c|}{ Chlorophyll Content $\left(\mathrm{mg} \mathrm{g}^{-1} \mathrm{FW}\right)$} & \multicolumn{3}{|c|}{ Carotenoid Content $\left(\mathrm{mg} \mathrm{g}^{-1} \mathrm{FW}\right)$} \\
\hline & 1 & 0.5 & 0.2 & 1 & 0.5 & 0.2 & 1 & 0.5 & 0.2 & 1 & 0.5 & 0.2 & 1 & 0.5 & 0.2 \\
\hline PM & $0.36^{a}$ & $0.38^{a}$ & $0.47^{a}$ & $77.52^{a b}$ & $68.55^{\text {abcd }}$ & $39.39^{a b c}$ & $11.80^{c d}$ & $27.1^{a b c}$ & $28.35^{a}$ & $4.27 a b c$ & $3.32^{a}$ & $2.79^{a}$ & $0.50^{a b c d}$ & $0.38^{a b}$ & $0.22^{a b}$ \\
\hline SH & $0.32^{a}$ & $0.50^{a}$ & $0.50^{a}$ & $79.61^{a b}$ & $70.82^{b c d}$ & $28.79 a b c$ & $6.15^{a}$ & $25.9 b c$ & $37.00^{c d}$ & $3.96 a b c$ & $3.53^{a}$ & $3.41^{a}$ & $0.51^{a b c d}$ & $0.50^{a b}$ & $0.63^{a b}$ \\
\hline GPM & $0.38^{a}$ & $0.57^{a}$ & $0.42^{a}$ & $78.06^{a b}$ & $55.06^{a b c d}$ & $43.64 a b c$ & $7.40^{\text {abcd }}$ & $23.2^{a b c}$ & $33.90^{a b c d}$ & $5.16^{b c}$ & $4.25^{a}$ & $4.46^{a}$ & $0.42^{a b c d}$ & $0.57^{a b}$ & $0.40^{a b}$ \\
\hline CM & $0.30^{a}$ & $0.38^{a}$ & $0.36^{a}$ & $81.52^{a b}$ & $67.75^{\text {abcd }}$ & $11.11^{a b c}$ & $6.25^{\text {abcd }}$ & $26.4^{a b c}$ & $30.80^{\text {abcd }}$ & $4.55^{a b c}$ & $3.42^{a}$ & $3.34^{a}$ & 0.25 abcd & $0.38^{a b}$ & $0.27^{a b}$ \\
\hline MPP & $0.35^{a}$ & $0.78^{a}$ & $0.46^{a}$ & $84.68^{a b}$ & $72.43^{c d}$ & $20.37 a b c$ & 8.65 abcd & $25.6 a b c$ & 31.95 abcd & $3.43 a b c$ & $3.41^{a}$ & $2.91^{a}$ & $0.72^{c d}$ & $0.78^{b}$ & $0.09^{a}$ \\
\hline HT & $0.26^{a}$ & $0.78^{a}$ & $0.37^{a}$ & $65.50^{a b}$ & $61.34_{\text {abcd }}$ & $38.24 a b c$ & 7.05 abcd & $20.8^{a b c}$ & $27.35^{a b}$ & $3.84 a b c$ & $3.90^{a}$ & $3.48^{a}$ & $0.81^{d}$ & $0.78^{b}$ & $0.33^{a b}$ \\
\hline GF & $0.27^{a}$ & $0.38^{a}$ & $0.30^{a}$ & $87.30^{b}$ & $69.82^{a b c d}$ & $18.63^{a b c}$ & 6.55 abcd & $24.4^{a b c}$ & $30.34 a b c$ & $4.91 a b c$ & $3.94^{a}$ & $3.72^{a}$ & $0.05^{a}$ & $0.38^{a b}$ & $0.36^{a b}$ \\
\hline GJ & $0.26^{a}$ & $0.70^{a}$ & $0.37^{a}$ & $70.64^{a b}$ & $59.62^{a b c d}$ & $33.76^{a b c}$ & 11.65 abcd & $27.2^{a b c}$ & $32.45 a b c$ & $4.99 a b c$ & $3.38^{a}$ & $3.28^{a}$ & $0.03^{a}$ & $0.70^{b}$ & $0.50^{a b}$ \\
\hline PMN & $0.32^{a}$ & $0.49^{a}$ & $0.47^{a}$ & $89.44^{b}$ & $62.41^{a b c d}$ & $19.43^{a b c}$ & $10.00^{a b c d}$ & $33.0^{c}$ & 33.25 abcd & $3.65 a b c$ & $4.09^{a}$ & $3.17^{a}$ & $0.49^{a b c d}$ & $0.49^{a b}$ & $0.55^{a b}$ \\
\hline GM & $0.25^{a}$ & $0.43^{a}$ & $0.30^{a}$ & $85.53^{a b}$ & $54.20^{a b c d}$ & $21.10^{a b c}$ & $7.20^{a b c d}$ & $26.7 a b c$ & $31.65 a b c$ & $3.82 a b c$ & $3.35^{a}$ & $3.22^{a}$ & $0.58^{a b c d}$ & $0.43^{a b}$ & $0.29^{a b}$ \\
\hline CK & $0.32^{a}$ & $0.44^{a}$ & $0.38^{a}$ & $76.95^{a b}$ & 57.29 abcd & $47.09 a b c$ & $7.65 \mathrm{abcd}$ & $28.3^{a b c}$ & $32.80^{a b c d}$ & $4.18^{a b c}$ & $4.31^{a}$ & $3.62^{a}$ & $0.68^{b c d}$ & $0.44^{a b}$ & $0.27^{a b}$ \\
\hline BSM & $0.32^{a}$ & $0.76^{a}$ & $0.55^{a}$ & $85.73^{a b}$ & $73.37^{d}$ & $58.94^{c}$ & 6.35 abcd & $21.1^{a b c}$ & $25.95^{a b}$ & $4.65 a b c$ & $4.40^{a}$ & $4.30^{a}$ & $0.11^{a b c}$ & $0.76^{b}$ & $0.79^{b}$ \\
\hline PMK & $0.27^{a}$ & $0.34^{a}$ & $0.40^{a}$ & $84.52^{a b}$ & 62.67 abcd & $27.03 a b c$ & $14.05 \mathrm{bcd}$ & $24.5 a b c$ & $31.55 a b c$ & $4.33 a b c$ & $4.07^{a}$ & $3.33^{a}$ & $0.01^{a}$ & $0.34^{a b}$ & $0.54^{a b}$ \\
\hline PPK & $0.32^{a}$ & $0.55^{a}$ & $0.31^{a}$ & $82.46^{a b}$ & 54.05 abcd & $52.63 b c$ & $8.60^{a b c d}$ & $31.1^{c}$ & $29.65 a b c$ & $3.58^{a b}$ & $3.91^{a}$ & $2.87^{a}$ & $0.29^{a b c d}$ & $0.55^{a b}$ & $0.17^{a}$ \\
\hline PHM & $0.21^{a}$ & $0.45^{a}$ & $0.41^{a}$ & $83.86^{a b}$ & $60.17^{a b c d}$ & $37.37 a b c$ & $9.15^{a b c d}$ & $24.0^{a b c}$ & $34.70^{a b c d}$ & $3.62^{a b}$ & $4.24^{a}$ & $3.07^{a}$ & $0.13 a b c$ & $0.45^{a b}$ & $0.48^{a b}$ \\
\hline PPM & $0.28^{a}$ & $0.52^{a}$ & $0.36^{a}$ & $86.81^{b}$ & 68.48 abcd & $59.07^{c}$ & $12.50^{c d}$ & $23.1^{a b c}$ & $40.70^{d}$ & $5.44^{c}$ & $2.74^{a}$ & $3.09^{a}$ & $0.09^{a b}$ & $0.52^{a b}$ & $0.41^{a b}$ \\
\hline GS & $0.27^{a}$ & $0.73^{a}$ & $0.52^{a}$ & $81.19^{a b}$ & $58.58^{a b c d}$ & $42.93 a b c$ & $8.75^{a b c d}$ & $30.5 a b c$ & 33.45 abcd & $4.97 a b c$ & $4.22^{a}$ & $4.14^{a}$ & $0.05^{a}$ & $0.73^{b}$ & $0.56^{a b}$ \\
\hline $\mathrm{CH}$ & $0.26^{a}$ & $0.03^{a}$ & $0.27^{a}$ & $70.77^{a b}$ & 64.35 abcd & $28.44^{a b c}$ & $14.25^{d}$ & $27.2^{b c}$ & 36.65 bcd & $3.51^{a}$ & $3.06^{a}$ & $2.35^{a}$ & $0.55^{a b c d}$ & $0.03^{a b}$ & $0.28^{a b}$ \\
\hline SB & $0.37^{a}$ & $0.49^{a}$ & $0.45^{a}$ & $77.76^{a b}$ & $52.19^{a}$ & $30.40^{a b c}$ & $9.10^{a b c d}$ & $27.9 b c$ & $26.30^{a b c d}$ & $4.69 a b c$ & $4.33^{a}$ & $4.29^{a}$ & $0.59^{a b c d}$ & $0.49^{a b}$ & $0.62^{a b}$ \\
\hline
\end{tabular}

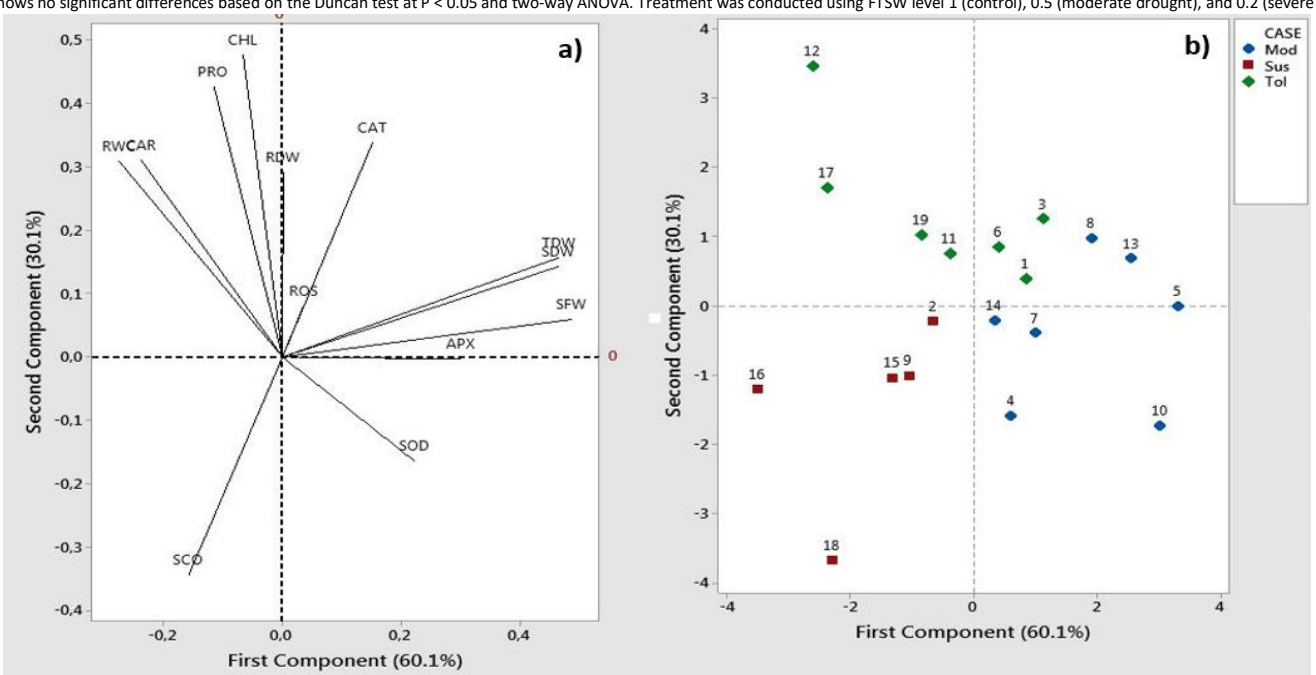

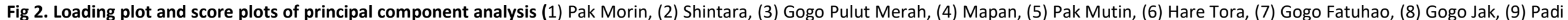

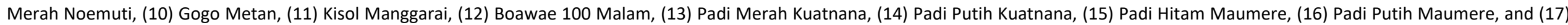

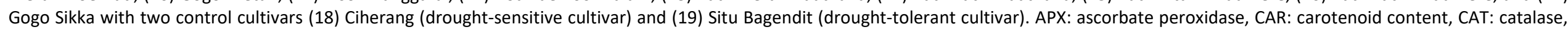

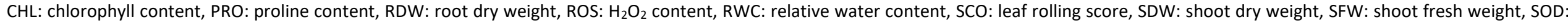
superoxide dismutase, TDW: total dry-weight. 
Table 3. Enzymatic antioxidant activity characteristics (SOD, CAT, APX) of 17 NTT local rice cultivars as affected by decreasing FTSWs

\begin{tabular}{|c|c|c|c|c|c|c|c|c|c|c|c|c|}
\hline \multirow{2}{*}{ Cultivar } & \multicolumn{3}{|c|}{$\operatorname{SOD}\left(\mathrm{U} \mathrm{L}^{-1}\right)$} & \multirow{2}{*}{$\operatorname{lnc}(\%)$} & \multicolumn{3}{|c|}{$\mathrm{CAT}\left(\mathrm{mmol} \mathrm{H} \mathrm{O}_{2} \mathrm{~min}^{-1} \mathrm{~g}^{-1} \mathrm{FW}\right)$} & \multirow{2}{*}{$\operatorname{lnc}(\%)$} & \multicolumn{3}{|c|}{$\operatorname{APX}\left(\mathrm{UL}^{-1}\right)$} & \multirow{2}{*}{$\begin{array}{l}\text { Inc } \\
\text { (\%) }\end{array}$} \\
\hline & 1 & 0.5 & 0.2 & & 1 & 0.5 & 0.2 & & 1 & 0.5 & 0.2 & \\
\hline PM & $17.3^{c}$ & $18.2^{c d}$ & $22.4^{a b}$ & 22.9 & $0.09^{a}$ & $0.29^{a b}$ & $0.47^{a}$ & 79.6 & $0.21^{a b}$ & $0.23^{a b}$ & $0.33^{a b c}$ & 36.8 \\
\hline $\mathrm{SH}$ & $4.9 a b c$ & $4.6^{a b}$ & $8.5^{a b}$ & 42.9 & $0.12^{a}$ & $0.21^{a b}$ & $0.21^{a}$ & 45.2 & $0.19^{a b}$ & $0.23^{a b}$ & $0.29 a b c$ & 35.3 \\
\hline GPM & $15.0^{b c}$ & $17.7^{c d}$ & $22.2^{a b}$ & 32.4 & $0.14^{a}$ & $0.11^{a}$ & $0.30^{a}$ & 55.0 & $0.21^{a b}$ & $0.26^{a b}$ & $0.33^{a b c}$ & 36.8 \\
\hline $\mathrm{CM}$ & $9.4^{a b c}$ & $21.5^{d}$ & $30.0^{b c}$ & 68.7 & $0.12^{a}$ & $0.26^{a b}$ & $0.28^{a}$ & 58.9 & $0.18^{a b}$ & $0.29^{a b}$ & $0.43^{b c}$ & 58.7 \\
\hline MPP & $1.2^{a}$ & $13.0^{a b c d}$ & $22.9^{a b}$ & 94.7 & $0.14^{a}$ & $0.26^{a b}$ & $0.39^{a}$ & 65.4 & $0.31^{b}$ & $0.35^{b}$ & $0.35^{a b c}$ & 10.0 \\
\hline HT & $12.0^{a b c}$ & $15.7^{b c d}$ & $17.7^{a b}$ & 32.1 & $0.13^{a}$ & $0.35^{a b}$ & $0.39^{a}$ & 67.9 & $0.07^{a}$ & $0.08^{a}$ & $0.24 a b c$ & 71.4 \\
\hline GF & $12.9^{a b c}$ & $17.3^{c d}$ & $19.5^{a b}$ & 34.1 & $0.09^{a}$ & $0.17^{a b}$ & $0.41^{a}$ & 77.8 & $0.19^{a b}$ & $0.28^{a b}$ & $0.42^{b c}$ & 54.2 \\
\hline GJ & $10.1^{a b c}$ & $13.3^{a b c d}$ & $21.2^{a b}$ & 52.6 & $0.14^{a}$ & $0.35^{a b}$ & $0.57^{a}$ & 76.3 & $0.10^{a}$ & $0.29 a b$ & $0.45^{c}$ & 78.2 \\
\hline PMN & $2.7^{a b}$ & $36.8^{e}$ & $45.8^{c}$ & 94.1 & $0.17^{a}$ & $0.22^{a b}$ & $0.27^{a}$ & 38.9 & $0.17^{a b}$ & $0.21^{a b}$ & $0.36^{a b c}$ & 52.4 \\
\hline GM & $7.2^{a b c}$ & $16.8^{c d}$ & $45.3^{c}$ & 84.1 & $0.11^{a}$ & $0.15^{a b}$ & $0.27^{a}$ & 61.1 & $0.05^{a}$ & $0.14^{a b}$ & $0.31 a b c$ & 83.3 \\
\hline CK & $5.9^{a b c}$ & $9.7^{a b c d}$ & $10.8^{a b}$ & 45.3 & $0.15^{a}$ & $0.35^{a b}$ & $0.39^{a}$ & 61.5 & $0.07^{a}$ & $0.24^{a b}$ & $0.23^{a b}$ & 69.2 \\
\hline BSM & $6.4^{a b c}$ & $10.7^{a b}$ & $20.3^{a b}$ & 68.5 & $0.11^{a}$ & $0.24^{a b}$ & $0.39^{a}$ & 73.1 & $0.16^{a b}$ & $0.12^{a b}$ & $0.28^{a b c}$ & 43.7 \\
\hline PMK & $17.0^{c}$ & $18.8^{c d}$ & $28.7^{b c}$ & 40.7 & $0.08^{a}$ & $0.15^{a b}$ & $0.53^{a}$ & 85.8 & $0.19^{a b}$ & $0.24^{a b}$ & $0.36^{a b c}$ & 47.6 \\
\hline PPK & $6.3^{a b c}$ & $13.5^{a b c d}$ & $22.1^{a b}$ & 71.3 & $0.13^{a}$ & $0.42^{b}$ & $0.49^{a}$ & 73.7 & $0.11^{a}$ & $0.28^{a b}$ & $0.42^{b c}$ & 73.6 \\
\hline PHM & $11.2^{a b c}$ & $12.2^{a b c d}$ & $28.6^{b c}$ & 61.0 & $0.07^{a}$ & $0.08^{a}$ & $0.38^{a}$ & 80.0 & $0.20^{a b}$ & $0.31^{a b}$ & $0.33^{a b c}$ & 40.4 \\
\hline PPM & $7.6^{a b c}$ & $9.1^{a b c}$ & $12.9^{a b}$ & 41.2 & $0.11^{a}$ & $0.18^{a b}$ & $0.27^{a}$ & 61.1 & $0.15^{a b}$ & $0.14^{a b}$ & $0.24^{a b c}$ & 38.1 \\
\hline GS & $0.2^{a}$ & $2.3^{a}$ & $5.9^{a}$ & 95.8 & $0.03^{a}$ & $0.2^{a b}$ & $0.53^{a}$ & 93.3 & $0.02^{a}$ & $0.16^{a b}$ & $0.23^{a b}$ & 92.3 \\
\hline $\mathrm{CH}$ & $7.0^{a b c}$ & $10.8^{a b c d}$ & $13.6^{a b}$ & 48.3 & $0.12^{a}$ & $0.26^{a b}$ & $0.23^{a}$ & 46.7 & $0.1^{a}$ & $0.19^{a b}$ & $0.17^{a}$ & 40.0 \\
\hline SB & $2.1^{a b}$ & $11.3^{a b c d}$ & $26.0^{a b c}$ & 91.9 & $0.15^{a}$ & $0.26^{a b}$ & $0.29^{a}$ & 45.6 & $0.05^{a}$ & $0.16^{a b}$ & $0.23^{a b}$ & 76.9 \\
\hline
\end{tabular}

(moderate drought), and 0.2 (severe drought). Inc (\%) shows increasing percentage from control condition to severe drought.

performance, as indicated by the reduction of plant height, the number of tillers, chlorophyll content, shoot dry weight, and root dry weight. These were inverse to the increase of enzymatic antioxidant activity and leaf rolling score as a response of each cultivar to severe drought conditions as reported by Salsinha et al. (2020). In several cultivars, although the physiological performance is decreased, the resulting reduction is smaller than that in plants that express relatively low enzymatic antioxidants.

\section{Materials and Methods}

\section{Plant materials}

The 19 rice (Oryza sativa) cultivars used in this study consisted of 17 local rice cultivars from NTT including PM_Pak Morin, SH_Shintara, GPM_Gogo Pulut Merah, CM_Mapan, PM_Pak Mutin, HT_Hare Tora, GF_Gogo Fatuhao, GJ_Gogo Jak, PMN_Padi Merah Noemuti, GM_Gogo Metan, CK_Kisol Manggarai, BSM_Boawae 100 Malam, PMK_Padi Merah Kuatnana, PPK_Padi Putih Kuatnana, PHM_Padi Hitam Maumere, PPM_Padi Putih Maumere, and GS_Gogo Sikka with two control cultivars: CH_Ciherang as drought susceptible cultivar and SB_Situ Bagendit as a drought-tolerant cultivar.

\section{Research location}

This research was conducted at the Sawitsari Research Station, Faculty of Biology, Universitas Gadjah Mada $\left(7^{\circ} 45^{\prime} 22^{\prime \prime} \mathrm{S}, 110^{\circ} 23^{\prime} 18^{\prime \prime} \mathrm{E}\right.$ with an altitude of $114 \mathrm{~m}$ above sea level) during 2018 to 2019. The area has an average annual rainfall of 243 to $348 \mathrm{~mm}$ with a temperature range between 25 and $34{ }^{\circ} \mathrm{C}$. The sun exposure ranged from $\sim 4500$ lux (in the morning) to $\sim 53000$ lux (during daylight) with humidity, air pressure, and velocity of $87 \%-88 \%, 995$ millibars, and $0.8-1 \mathrm{~m} / \mathrm{s}$, respectively.

\section{Experimental design and cultivation treatments}

Drought treatments performed using the FTSW (Fraction of transpirable soil water) method (Serraj et al., 2008) with three levels of treatments consisted of FTSW 1 (control), FTSW 0.5 (moderate drought stress), FTSW 0.2 (severe drought stress). Before the treatment of FTSW, each cultivar was grown under $100 \%$ field capacity (gravimetry method). The calculation of total transpirable soil water (TTSW) was performed after it reached the permanent wilting point (indicated by stable pot and crop weight). The TTSW of each cultivar calculated using PO (initial pot and plant weight at $100 \%$ field capacity) and $\mathrm{Pi}$ (pot and plant weight at the permanent wilting point) with the formula:

$$
T T S W=P 0-P i
$$

To maintain the stability of each level of FTSW treatment, the value of Pt (pot and plant weight at any given time) and Wt (water amount that should be kept permanent for each FTSW level) calculated using the formula:

$$
\begin{gathered}
W t=F T S W \text { level }(1 ; 0.5 \text { or } 2) \times T T S W \\
P t=P 0-(\text { TTSW }-W t)
\end{gathered}
$$

Each germinated seedling (21 days after imbibition) transferred into $1 \mathrm{~kg}$ of the individual plastic pot (with a diameter of $15 \mathrm{~cm}$ ) contained soil and compost (with the ratio of 3:1). The research design was carried out accordingly to randomized complete block design with a total number of the samples were 228 samples consisted of three levels of drought treatments, 19 cultivars, and four replications). All the cultivars should maintain each level of treatment after seven days of acclimatization. The growth parameters were measured at 49 days after planting (DAP), while the physiological parameters were observed between $42-49$ DAP.

\section{Observation and variables evaluated}

Growth parameters, including plant height, root length, number of leaves, and tillers, were recorded at the end of observation (49) DAP). Fresh weight and dry weight were weighed with digital scales (ACIS, BC-500). All plant parts were dried in an oven at $75^{\circ} \mathrm{C}$ for four days to obtain the dry weight. For pigments measurement, leaf samples were crushed and extracted in $80 \%$ cold acetone. Chlorophyll (Chla, Chlb, total Chl) and carotenoids content were measured by using the Harborne method (1984) with a spectrophotometer (GENESYS 10 UV Scanning, Thermo Fisher Scientific) and expressed as $\mathrm{mg} \mathrm{g}^{-1}$ fresh weight (FW). Proline content was determined spectrophotometrically based on Bates et al. (1973) method using the calibration of a proline standard curve. For antioxidant enzyme analysis, samples from each plant were taken and homogenized in 50 $\mathrm{mM}$ potassium phosphate buffer $(\mathrm{pH} 7)$ containing one $\mathrm{mM}$ and $1 \%(\mathrm{~b} / \mathrm{v})$ EDTA. Supernatants were used as enzyme samples (Sunkar, 2010; Elavarthi and Martin, 2010). The 
superoxide dismutase (SOD) activity was measured using the method by Marklund and Marklund (1970). The absorbance of the enzyme solution was measured with a spectrophotometer at $\lambda 325 \mathrm{~nm}$. The enzyme activity was expressed by $50 \%$ inhibition of pyrogallol autoxidation activity within 3 mins. For catalase (CAT) activity, the absorbance of the sample was measured at $\lambda 240 \mathrm{~nm}$ for 2 minutes. This method was performed following Elavarthi and Martin (2010). The enzymatic activity of ascorbate peroxidase (APX) was measured at $\lambda 290 \mathrm{~nm}$. The rate of ascorbic oxidation reactions was calculated according to Elavarthi and Martin (2010). Relative water content (RWC) analysis was carried out following Mullan and Pietragalla (2011) with several modifications. The leaf samples were weighed as initial fresh weight (FW) and $\mathrm{dd}_{2} \mathrm{O}$ was added before incubation. The leaf pieces were weighed again to determine the turgid weight (TW) and dried at $75^{\circ} \mathrm{C}$ for 48 hours and reweighed to obtain the leaf sample dry weight (DW).

\section{Data analysis}

The significance of the data and the effect of FTSW treatment on plant height, number of tillers, plant biomass parameters of biochemical activity, and other enzymes (SOD, APX, CAT) tested using two-way ANOVA. The analysis continued with the Duncan test conducted at a $95 \%$ confidence level. All data were analyzed statistically by using IBM SPSS Ver. 20.0 (US). The accumulated data of plant height, number of tillers, plant biomass parameters of biochemical activity, and other enzymes (SOD, APX, CAT) then subjected to principal component analysis (Mau et al., 2019) using XLSTAT 2020 and MINITAB 19.0.

\section{Conclusion}

Under stress conditions, the mechanism of oxidative defense was increased to ensure the tolerance of plants due to the increase in ROS production. The drought tolerance of rice cultivars was observed in various parameters such as the higher content of Prolin and enzymatic antioxidant activities. In this study, cultivars with high tolerance to drought stress are Boawae 100 malam, Gogo Sikka, Kisol Manggarai, Hare Tora, Gogo Pulut Merah, and Pak Morin, while Shintara, Padi Merah Noemuti, Padi Hitam Maumere, and Padi Putih Maumere considered as drought susceptible cultivars.

\section{Acknowledgment}

The authors are grateful for the financial support provided by the Directorate of Research and Community Service; the Directorate General of Research and Development Strengthening; the Ministry of Research, Technology, and Higher Education; and the Directorate of Research at Universitas Gadjah Mada under a PMDSU research grant (2019-2020). The authors are also grateful to the Faculty of Biology UGM as a provider of research facilities.

\section{References}

Aroca R, Ruiz-Lozano JM (2012) Regulation of root water uptake under drought stress conditions. In: Aroca R (ed) Plant response to drought stress. Springer, Berlin. 113.

Ashraf M, Akram NA, Al-Qurainy F, Foolad MR (2011) Drought tolerance: roles of organic osmolytes, growth regulators and mineral nutrients. Adv Agron. 111: 249-296
Bates LS, Waldran RP, Teare ID (1973) Rapid determination of free proline for water-stress studies. Plant soil. 39: 205.

Chaves MM, Costa JM, Saibo, NJM (2011) Recent advance in photosynthesis under drought and salinity. Adv Bot Res. 57: 49-104.

Centritto M, Lauteru M, Monteverdi MC, Serraj R (2009) Leaf gas exchange, carbon isotope discrimination, and grain yield in contrasting rice genotypes subjected to water deficits during the reproductive stage. J Exp Bot. 60(8): 2235-2339.

Elavarthi S, Martin B (2010) Spectrophotometric assays for antioxidant enzymes in plants. Plant stress tolerance. Methods Mol Biol. 639: 273 280.

Farooq M, Hussain M, Wahid A, Siddique KHM (2012) Drought stress in plants: an overview. In: Aroca R (ed) Plant response to drought stress. Springer. Berlin.1-33.

Foyer CH, Noctor G (2003) Redox sensing and signaling associated with reactive oxygen in chloroplast, peroxisomes and mitochondria. Physiol Plantarum. 119: 355-364.

Gechev TS, Van Breusegem F, Stone JM, Denev I, Laloi C (2006) Reactive oxygen species as signals that modulate plant stress responses and programmed cell death. Bioessays. 28:1091-1101

Harborne JB (1984) Phytochemical Methods: a guide to modern technique of plant analysis. (2nd ed). Chapman and Hall. London. 37168.

Hayat, Hayat SQ, Almeny MN, Wani AS, Pitchel J, Ahmad A (2012) Role of proline under changing environments a review. Plant Signal Behav. 7:1-11.

Lalel HJD, Abidin Z, Jutomo L (2009) The physico-chemical properties of local upland brown rice in Ende. J Tek Ind Pangan., 20:109-116 (In Indonesia).

Marklund S, Marklund G (1974) Involvement of the superoxide anion radical in the autoxidation of pyrogallol and a convenient assay for superoxide dismutase. Eur J Biochem. 47: 469-474.

Mau, YS, Ndiwa ASS, Oematan SS, Markus JER (2019) Drought tolerance indices for selection of drought tolerant, high yielding upland rice genotypes. Aust J Crop Sci. 13 (01): 170-178.

McMaster GS, Wilhelm WW (2003) Phenological response of wheat and barley to water and temperature: improving simulation models. J Agr Sci. 141: 129-147.

Mittler R (2002) Oxidative stress, antioxidants and stress tolerance. Trends Plant Sci. 7(9): 405-410.

Mullan D, Pietragalla J (2012) Leaf relative water content. In: Pietragalla J, Mullan D, Reynolds M (ed) Physiological breeding II: A field guide to wheat phenotyping. CIMMYT, Mexico. 25-27.

Neumann PM (2011) Recent advances in understanding the regulation of whole-plant growth inhibition by salinity, drought and colloid stress. Adv Bot Res.57: 33-48.

Pandey V, Shukla A. 2015. Acclimation and tolerance strategies of rice under drought stress. Rice Sci. 22(4): 147-161.

Refli, Muljopawiro S, Dewi K, Rachmawati D (2014) Expression Analysis of antioxidant genes in response to drought stress in the flag leaf of two Indonesian rice cultivars. Indonesian J Biotech. 19: 43-55.

Refli, Purwestri YA (2016) The response of antioxidant genes in rice (Oryza sativa) seedling cv. Cempo Ireng under drought and salinity stresses. AIP Conf Proc 1744, 020047-1-020047-8.

Salsinha YCF, Indradewa D, Purwestri YA, Rachmawati D (2020) Selection of drought-tolerant local rice cultivars from East Nusa Tenggara, Indonesia during begetative stage. Biodiversitas. 21(1): 170-178.

Serraj R, Liu D, He H, Sellamuthu R, Impa S, Cairns J, Dimayuga $G$ and Torres $R$ (2008). Novel approaches for integration of physiology, genomics and breeding for drought resistance improvement in rice. Drydown FTSW Protocol, IRRI. Manila.

Singh M, Kumar J, Singh S, Singh VP, Prasad SM (2015) Roles of osmoprotectants in improving salinity and drought tolerance in plants: a review. Rev Environ Sci Biotechnol. 14:407-426.

Siswanti DU, Rachmawati D (2011) Plant response and nitrate reductase activity in vivo on rice (Oryza sativa L.) cultivars IR64 to biofertilizer application and drought. AIP Proceed. 1-5.

Sunkar R (2010) Plant stress tolerance- methods and protocols. Springer Protocols. Humana Press. London. 273-280.

Tripathy JN, Zhang JX, Robin S, Nguyen TT, Nguyen HT (2000) QTLs for cell-membrane stability mapped in rice (Oryza sativa L.) under drought stress. Theor Appl Genet. 100(8): 1197-1202.

Xia $\mathrm{H}$, Huang WX, Xiong J, Tao T, Zheng XG, Wei HB, Yue YX, Chen L, Luo LJ (2006) Adaptif epigenetic differentiation between upland and lowland rice ecotype revealed by methylation-sensitive amplified polymorphism, PloS One 11, https://doi.org/10.1371/journal.pone.0157810. 